\title{
En baker med astma
}

\author{
En mann i 30-årene med mistenkt bakerastma hadde sluttet som baker \\ for å unngå å utvikle kronisk astma. Sykehistorien passet med diagno- \\ sen, men det var ikke blitt utført objektiv astmadiagnostikk mens pasien- \\ ten var i eksponering. På grunn av videre yrkesvalg og de økonomiske \\ konsekvensene en arbeidsbetinget astma ville kunne gi i fremtiden, \\ $ø$ nsket pasienten en sikker diagnose.
}

En mann i 30-årene ble henvist til Yrkesmedisinsk avdeling med spørsmål om bakerastma. Pasienten hadde de siste fem àr hatt symptomer fra nese og øyne med rødhet, svie og renning når han var på jobb. Symptomene startet straks han startet arbeidsdagen og hadde gradvis økt på. Pasienten hadde de siste par årene også hatt problemer med tiltakende tungpustethet og pipelyder fra brystet, også disse symptomene på jobb. I begynnelsen av forløpet ble pasienten bedre raskt etter arbeidsdagens slutt, etter hvert ble symptomene kroniske og han ble kun bedre $i$ ferier og lengre friperioder, og til slutt opplevde pasienten at han var dårlig hele tiden. Han sluttet ijobben på grunn av dette, men ønsket en sikker etiologisk diagnose.

Eksponering for melstøv i bakerier har vært en kjent årsak til astma siden 1700-tallet (1). Melstøv inneholder en rekke allergener og slimhinneirritanter, slik som proteiner fra mel, enzymer, bakterier, sopp, fragmenter fra insekter og krydder, som alle kan forårsake yrkesastma hos bakere (1). Sen diagnose og intervensjon fører i mange tilfeller til at sykdommen blir kronisk (2). Om melstøveksponering over tid også disponerer for kronisk obstruktiv lungesykdom (kols) er i økende grad diskutert (3).

Under utredningen ved Yrkesmedisinsk avdeling var pasienten under omskolering og hadde vært utenfor eksponering i nærmere ett år. Ved undersøkelse var han respiratorisk ubesværet i hvile og ved lett fysisk aktivitet. Det var normale respirasjonslyder uten piping, regelmessig hjerteaksjon og ingen bilyd over cor. Pasienten hadde positiv prikktest (+3; referanseverdi 0) på hvetemel, rugmel, bakerenzymet $\alpha$-amylase og lagermidden Acarus Siro, svakere reaksjon (+1) på lagermiddene Lipidoglyphus destructor og Tyrophagus putrescentiae, og negativ reaksjon på havremel. Serum-IgE ga utslag på hvete, rug, bygg og lagermidd (A. Siro og T. putrescentiae). For vurdering av lungefunksjon målte vi forsert vitalkapasitet
(FVC), forsert ekspiratorisk volum i løpet av første sekund (FEV), andelen av totalt luftvolum som blåses ut i løpet av første sekund (FEV $/$ /FVC) og ekshalert nitrogenmonoksid, som er en markør på inflammasjon i luftveiene. Undersøkelsen viste $F E V_{1}$ 3,43l (74 \% av forventet; normalområde $\geq 80 \%$ av forventet), FVC 4,59 ( $82 \%$ av forventet; normalområde $\geq 80 \%$ av forventet), FEV 1 /FVCratio $75 \%$ (normalområde $\geq 70 \%$ ), ekshalert nitrogenmonoksid på 30 ppb lparts per billion; referanse: $\leq 25 \mathrm{ppb}$ : eosinofil inflammasjon usannsynlig; <50 ppb: eosinofil inflammasjon sannsynlig) (4), og negativ metakolintest.

Pasienten hadde altså lett redusert $\mathrm{FEV}_{1}$, men ikke obstruktiv ventilasjonsinnskrenkning. Selv med en typisk sykehistorie på bakerastma og påvist IgE-mediert allergi mot hvetemel, rugmel, bakerenzymet $\alpha$-amylase og lagermidd, samt fravær av symptomer utenfor eksponering, reises det erfaringsmessig gjerne tvil om diagnosen bakerastma i forhold til erstatning (5). Ettersom det ikke var blitt utført objektiv astmadiagnostikk mens pasienten var i eksponering, og det ikke lenger var mulig å få gjennomført en registrering av toppstrømshastighet (PEF) i arbeid og fritid (2), ble det funnet indikasjon for å utføre en spesifikk bronkial provokasjon mot melstøv for nærmere diagnostikk. Provokasjonen ble utført etter anbefalinger publisert av en arbeidsgruppe nedsatt av European Respiratory Society (ERS), som har vurdert metoden med tanke på risiko, prosedyre og tolkning (6).

Provokasjonen ble utført $i$ et kammer på ca. $13 \mathrm{~m}^{3}$ der pasienten helte en 1:1-blanding av mel og laktose fra en bolle til en annen ca. $30 \mathrm{~cm}$ fra ansiktet i totalt fem minutter, slik at luften ble forurenset med støv. Siden prikktesten viste at pasienten reagerte kraftigst på rug, ble det besluttet å provosere pasienten med rugmel. Konsentrasjonen av støv i kammerluften ble målt med et personbåret direktevisende måleinstrument, og under testen lå denne på

\author{
Jorunn Kirkeleit \\ Yrkesmedisinsk avdeling \\ Haukeland universitetssykehus \\ og \\ Klinisk institutt 2 \\ Universitetet i Bergen \\ Tor Olav Brøvig Aasen \\ Yrkesmedisinsk avdeling \\ Lene Løvendahl Svendsen \\ Lungeavdelingen \\ Haukeland universitetssykehus

\section{Cecilie Svanes} \\ cecilie.svanes@helse-bergen.no \\ Yrkesmedisinsk avdeling \\ Haukeland universitetssykehus \\ og \\ Senter for internasjonal helse \\ Universitetet i Bergen
}




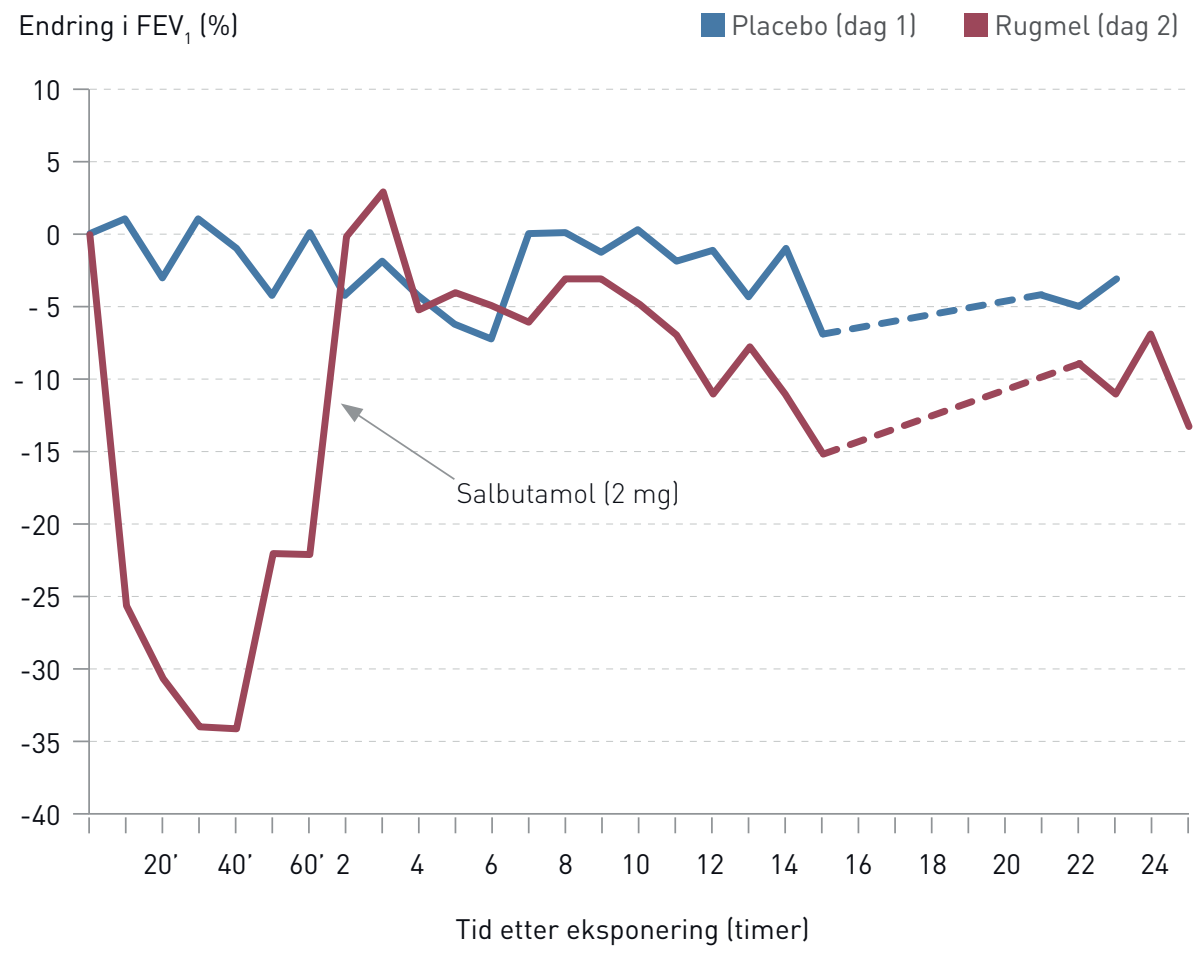

Figur 1 Endring i lungefunksjon som respons på eksponering for placebo og rugmel. Stiplet linje indikerer natt (ingen målinger)

rundt $3 \mathrm{mg} / \mathrm{m}^{3}$, som tilsvarer øvre grense for hva Arbeidstilsynet mener en arbeidstaker i gjennomsnitt kan utsettes for $i$ løpet av en åtte timers arbeidsdag (grenseverdi). Pasienten mente at støvnivået kunne likne det på jobb og at støvlaget ved endt provokasjon kunne likne det på jobb mot slutten av arbeidsdagen. Dagen før provokasjon ble pasienten på samme måte provosert for placebo bestående av laktose, et finkornet pulver som kan minne om mel.

Basert på eksponeringsmålingene, pasientens egenvurdering av eksponeringsnivå og målinger fra egne kartlegginger i norske bakerier (7) konkluderte vi med at konsentrasjonen pasienten ble eksponert for i provokasjonskammeret var realistisk.

Pasienten hadde ingen signifikant reaksjon på placebo: egenregistrerte $F E V_{1}$-målinger utover dagen var stabile med variasjoner under $10 \%$, og utover litt nesetetthet hadde han ikke symptomer (fig 1). Ved spesifikk provokasjon for melstøv fikk pasienten symptomer allerede etter ett minutts provokasjon: irritasjon av øyne, rennende nese, nysing og hosting samt følelse av å være tett i brystet og ha tung pust. Ved auskultasjon hørtes grovere respirasjonslyder, forlenget ekspirium og antydet piping i brystet. Videre provokasjon i fire minutter ga en økning i symptomene, et signifikant fall i FEV 1 på ca.
$26 \%$ etter 30 sekunder, og ytterligere fall til ca. 34\% 30-40 minutter etter provokasjon. Laveste målte verdi var 2,12 l. FEV økte deretter spontant til 3,05 l og steg ytterligere til 3,44 l etter inhalasjon av salbutamol.

Lungefunksjonsmålingene $\left(\mathrm{FEV}_{1}\right)$ utover ettermiddag og kveld var antydet lavere enn ved basis og betydelig mer variable enn de to foregående dagene. $\mathrm{FEV}_{1}$ falt med opp mot $15 \%$ ved midnatt, noe som kan indikere at pasienten også hadde en senreaksjon (fig 1).

Lungefysiologisk utredning dagen etter positiv test (posttestutredning, dag 3) sammenliknet med pretest (dag 0) viste betydelig økning i ekshalert nitrogenmonoksid 130 ppb til 81 ppb). Lungefunksjonstestene viste FVC på 5,12 ( (92\% av forventet), FEV 1,56 l (76\% av forventet) og FEV 1 /FVC-ratio $70 \%$. Disse var stort sett uforandret fra pretest. Strømningsvolumkurven hadde liknende hengekøyefasong før og etter provokasjon, forenlig med obstruksjon i luftveiene. Som ved pretest var metakolintesten negativ etter provokasjonen. Undersøkelser av øvre luftveier var upåfallende.

Det ble konkludert med at pasienten hadde en klart signifikant positiv provokasjonstest etter eksponering for rugmelstøv med sikker straksreaksjon og mulig senreaksjon, altså en antydet bifasisk reaksjon (fig 1). Han reagerte med både rhinitt og astma, begge deler bekreftet ved signifikante endringer $\mathrm{i}$ objektive målinger i øvre (resultater ikke vist) og nedre luftveier. Pasientens økning i ekshalert nitrogenmonoksid tyder på at innåndingen av rugmel hadde gitt en eosinofil inflammasjon i luftveiene. Melding om yrkessykdom ble sendt til Arbeidstilsynet.

\section{Diskusjon}

Påvisning av arbeidsbetinget astma forårsaket av et allergen vil som regel få betydelige konsekvenser for pasientens videre arbeidsliv. Spesielt gjelder at vedvarende eksponering etter diagnose innebærer stor risiko for kronisk astma. Personer som må skifte arbeid for å unngå å få en kronisk sykdom, som ville ha utløst økonomisk kompensasjon, vil i mange tilfeller få en markert forverret økonomi $(2,8)$.

Diagnosen arbeidsbetinget astma blir i praksis oftest stilt uten objektiv diagnostikk. Dette medfører betydelig innslag av falskt positive og falskt negative diagnoser og kan føre til at man gir feil råd til pasienten (5). Dette aktualiserer behovet for objektiv diagnostikk. Arbeidsanamnese sammen med allergologisk diagnostikk muliggjør identifisering av allergenet som har forårsaket astmaen. Påvist sensibilisering mot et allergen beviser imidlertid ikke alltid at dette er årsaken til pasientens astma. Måling av toppstrømshastigheten (PEF) $\mathrm{i}$ arbeid og fritid kan i mange tilfeller dokumentere sammenhengen mellom allergeneksponering og luftveisobstruksjon. Denne må imidlertid utføres mens pasienten fortsatt er i arbeid. Påvisning av $\operatorname{IgE}$ bekrefter sensibilisering, men sikrer ikke at testen har klinisk relevans og bekrefter ikke årsakssammenheng (9).

Positiv metakolintest, sammen med positiv prikktest og/eller spesifikk IgE mot relevante allergener, vil i de fleste tilfeller gi en god indikasjon på at det foreligger arbeidsbetinget astma (10). I det foreliggende tilfellet var metakolintesten negativ, noe som ikke er uvanlig ett år etter avsluttet eksponering, og det fantes ingen objektiv diagnostikk av astma mens pasienten var under eksponering. En del pasienter opplever å få avvist søknad om yrkessykdom hvis det ikke foreligger objektiv diagnostikk, og særlig en negativ metakolintest blir noen ganger feiltolket som fravær av gjennomgått astma. På dette grunnlaget fant vi en indikasjon for spesifikk bronkial provokasjon som kunne muliggjøre en nøyaktig årsaksdiagnose (11).

Spesifikk bronkial provokasjon (specific inhalation challenge, SIC) anses som referansemetode ved årsaksdiagnostikk av allergisk yrkesastma $(2,6)$. Metoden har tidligere vært i omfattende bruk i Norge innen allergologisk praksis, men har gått ut av bruk i dette fagfeltet (12). I dag benyttes den 
i utvalgte tilfeller der konvensjonell diagnostikk ikke kan gjennomføres eller har gitt usikre svar, når det er viktig å finne det spesifikke allergenet som forårsaker astma, eller når ny årsak til yrkesbetinget astma mistenkes. Spesifikk bronkial provokasjon gjøres som et laboratorieforsøk der pasienten utsettes for det stoffet som mistenkes å være årsak til luftveisplager eller astma i økende konsentrasjon og/eller økende eksponeringstid. Lungefunksjon $\left(\mathrm{FEV}_{1}\right)$ og klinisk status registreres hver time i våken tilstand, og pasienten følges tett av lungelege gjennom en hel uke. Testmateriale kan være både høymolekylære (proteiner, organisk støv, enzymer, muggsopp mv.) og lavmolekylære (isocyanater, epoksy, metallforbindelser mv.) stoffer. Testen regnes som positiv ved et fall i FEV 1 på $\geq 15 \%$ (6). Provokasjonen gjøres placebokontrollert der dette er mulig.

For denne pasienten med en klassisk sykehistorie på bakerastma, men negativ metakolintest, normal spirometri og normal ekshalert nitrogenmonoksid under senere utredning, samt manglende PEF-registreringer mens han ennå var under eksponering, var spesifikk bronkial provokasjon en nyttig diagnostisk metode, der man gjennom å følge pasienten over flere dager med lungefunksjonstester og kliniske observasjoner fikk en sikker diagnose og en sikker etiologi. Diagnostikken ved denne metoden, der pasienten fikk et tydelig astmaanfall etter kun fem minutters eksponering for normale nivå av melstøv, ga et langt sikrere grunnlag for alvorlig inngripen $\mathrm{i}$ pasientens yrkesliv. Undersøkelsen var også forbundet med en betydelig læringseffekt og bedre sykdomsforståelse for pasienten.

Flere av pasientene som har vært til vurdering for yrkesrelatert bakerastma hos oss har uventet fătt diagnosen hypersensitivitetspneumonitt (allergisk alveolitt) (13). Ved provokasjon for melstøv har de fått utpregede allmensymptomer som hodepine og sykdomsfølelse, lett temperaturstigning og dyspné, men ikke fall i FEV 1 . Vi har ved tre tilfeller gjort ny provokasjon med monitorering med blant annet FVC og gassdiffusjon (TLCO), og har da kunnet stille diagnosen hypersensitivitetspneumonitt, selv om vi ikke har eksponert pasienten tilstrekkelig til å gi endringer på CT. Vår erfaring er at denne tilstanden er betydelig underdiagnotisert. Spesifikk bronkial provokasjon brukes ved utredning av yrkesrelatert allergisk alveolitt ved noen få sentre i Europa, og utredningen gjøres etter en annen og mer krevende protokoll enn den som brukes ved mistanke om yrkesastma.

Diagnostikk med spesifikk bronkial provokasjon er komplisert, blant annet fordi det kan gjøres provokasjon med hundrevis av ulike substanser med like mange placebosubstanser. Det å bestemme riktig eksponering krever erfaring, og det er en viss risiko for å utløse kraftige astmaanfall. Vi mener derfor at diagnostikken bør gjøres for et tilstrekkelig stort antall pasienter ved få og spesialiserte sentre og i kommunikasjon med det internasjonale fagmiljøet. Yrkesmedisinsk avdeling ved Haukeland universitetssykehus har innført spesifikk bronkial provokasjon som diagnostisk metode. Ved en eventuell henvisning av pasient med mistenkt yrkesrelatert sykdom påpekes det at det vanligvis vil være vanskelig å avklare saker med spesifikk bronkial provokasjon når eksponeringen ligger mer enn et par år tilbake i tid. En henvisning bør inneholde en spesifisering av problemstillingen, arbeidshistorie og mistenkt eksponering, inkludert informasjon om hva produktene inneholder av mulige allergener, symptomer og symptomutvikling og tidligere sykdommer.

\section{Oppsummering}

Det å få yrkesastma fører til en stor omveltning i en pasients liv, vanligvis med en dårligere økonomisk situasjon som følge. Det er derfor imperativt at diagnosen er riktig, og at pasienten selv er overbevist og motivert for en så betydelig omlegging av livet. Spesifikk bronkial provokasjon er krevende for pasienten og for samfunnet, men kan for unge mennesker med mange yrkesaktive år foran seg være svært viktig i en kritisk fase. I flere tilfeller kan metoden hindre utvikling av en kronisk astma - som i stedet for en ukes utredning kan kreve 40 års sykelighet og behandling. Videre er det svært viktig å forsøke å påvise den spesifikke årsaken til yrkessykdom for å kunne identifisere nye stoffer blant de mange hundre som årlig innføres i norsk arbeidsliv. Slik kan vi eventuelt få fjernet astmafremkallende stoffer og beskytte arbeidstakere generelt, ikke bare den enkelte pasient.

Pasienten har gitt samtykke til at artikkelen blir publisert.

\section{Jorunn Kirkeleit (f. 1972)}

er ph.d., fysiolog, yrkeshygieniker og forsker Forfatter har fylt ut ICMJE-skjemaet og oppgir ingen interessekonflikter.

\section{Tor Olav Brøvig Aasen (f. 1946)}

er spesialist i indremedisin og i lungesykdommer, med spesiell kompetanse innen arbeidsrelaterte lungesykdommer. Han er tidligere avdelingsoverlege og avdelingsdirekt $\varnothing r$, nå spesialrådgiver og pensjonist. Forfatter har fylt ut ICMJE-skjemaet og oppgir ingen interessekonflikter.

\section{Lene Løvendahl Svendsen (f. 1952)}

er bioingeniør med spesialkompetanse i respirasjonsfysiologi. Hun er overbioingeniør og testansvarlig for lungefunksjonsmålinger gjort på respirasjonsfysiologisk laboratorium.

Forfatter har fylt ut ICMJE-skjemaet og oppgir ingen interessekonflikter.

\section{Cecilie Svanes (f. 1962)}

er spesialist $\mathrm{i}$ indremedisin og i lungesykdommer, med spesialkompetanse innenfor arbeidsrelaterte lungesykdommer. Hun er overlege og professor

Forfatter har fylt ut ICMJE-skjemaet og oppgir ingen interessekonflikter.

\section{Litteratur}

1. Brisman J. Baker's asthma. Occup Environ Med 2002; 59: 498-502.

2. Aasen TO, Kongerud J. Arbeidsrelatert astma diagnostikk og oppfølging. Tidsskr Nor Legeforen 2014; 134: 1955-9.

3. Mannino DM, Buist AS. Global burden of COPD risk factors, prevalence, and future trends. Lancet 2007; 370: 765-73.

4. Dweik RA, Boggs PB, Erzurum SC et al. An official ATS clinical practice guideline: interpretation of exhaled nitric oxide levels (FENO) for clinical applications. Am J Respir Crit Care Med 2011; 184: $602-15$

5. Malo JL, Ghezzo H, L'Archevêque J et al. Is the clinical history a satisfactory means of diagnosing occupational asthma? Am Rev Respir Dis 1991: 143: $528-32$

6. Vandenplas O, Suojalehto H, Aasen TB et al. Specific inhalation challenge in the diagnosis of occupational asthma: consensus statement. Eur Respir J 2014: 43: 1573-87.

7. Storaas T, Ardal L, Van Do T et al. Nasal indices of eosinophilic and exudative inflammation in bakery-workers. Clin Physiol Funct Imaging 2007; 27: $23-9$

8. Wergeland E. I strid med arbeidervernloven. Dagens Medisin nr. 21/2011. www.dagensmedisin.no/ artiklar/2011/12/14/i-strid-med-arbeidervernloven/ (13.5.2015).

9. Crameri R. The crux with a reliable in vitro and in vivo diagnosis of allergy. Allergy 2013; 68 $693-4$

10. Beach J, Russell K, Blitz S et al. A systematic review of the diagnosis of occupational asthma. Chest 2007: 131: 569-78.

11. Lemière C, Cartier A, Malo JL et al. Persistent specific bronchial reactivity to occupational agents in workers with normal nonspecific bronchial reactivity. Am J Respir Crit Care Med 2000; 162 976-80.

12. Aas K. Bronchial provocation tests in asthma. Arch Dis Child 1970; 45: $221-8$

13. Munoz X, Morell F, Cruz MJ. The use of specific inhalation challenge in hypersensitivity pneumonitis. Curr Opin Allergy Clin Immunol 2013; 13: $151-8$

Mottatt 18.12. 2014, første revisjon innsendt 18.3. 2015, godkjent 13.5. 2015. Redaktør: Lise Mørkved Helsingen. 